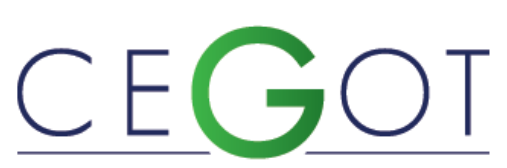

Centro de Estudos de Geografia e Ordenamento do Território
Geografia e Ordenamento do Território, Revista Eletrónica Centro de Estudos de Geografia e Ordenamento do Território http://cegot.org

GuerRa, Rosana

Fundação Estadual de Planejamento Metropolitano e Regional, Divisão de Planejamento Urbano Regional -METROPLAN -

Centro Administrativo Fernando Ferrari

Av. Borges de Medeiros $1501-4^{\circ}$ andar Ala Norte, Porto Alegre - RS. CEP:

90119.900 Brasil

ropradoliveira@gmail.com

Monteiro, DeYVID

Fundação Estadual de Planejamento Metropolitano e Regional, Divisão de Planejamento Urbano Regional -METROPLAN Centro Administrativo Fernando Ferrari

Av. Borges de Medeiros 1501 - 4 andar Ala Norte, Porto Alegre - RS. CEP: 90119.900 Brasil

deyvidalex@hotmail.com

Mengue, Vagner

Fundação Estadual de Planejamento Metropolitano e Regional, Divisão de Planejamento Urbano Regional -METROPLAN -

Centro Administrativo Fernando Ferrari

Av. Borges de Medeiros 1501 - 4ํandar Ala Norte, Porto Alegre - RS. CEP: 90119.900 Brasil

vagnergeo@yahoo.com.br

\section{SANTOS, LETíCIA}

Fundação Estadual de Planejamento Metropolitano e Regional, Divisão de Planejamento Urbano Regional -METROPLAN -

Centro Administrativo Fernando Ferrari

Av. Borges de Medeiros 1501 - 4ํandar Ala Norte, Porto Alegre - RS. CEP:

90119.900 Brasil

leticia-machado@metroplan.rs.gov.br

Oliveira, Carolina

Fundação Estadual de Planejamento Metropolitano e Regional, Divisão de Planejamento Urbano Regional -METROPLAN Centro Administrativo Fernando Ferrari

Av. Borges de Medeiros 1501 - 4ํandar Ala Norte, Porto Alegre - RS. CEP: 90119.900 Brasil

carolina.vaaz@hotmail.com

Bertoglio, ElizABETH

Fundação Estadual de Planejamento Metropolitano e Regional, Divisão de Planejamento Urbano Regional -METROPLAN -

Centro Administrativo Fernando Ferrari

Av. Borges de Medeiros 1501 - 4ํandar Ala Norte, Porto Alegre - RS. CEP: 90119.900 Brasil

elizabeth-bertoglio@metroplan.rs.gov.br

FREITAS, CILULIA

Fundação Estadual de Planejamento Metropolitano e Regional, Divisão de Planejamento Urbano Regional -METROPLAN -

Centro Administrativo Fernando Ferrari

Av. Borges de Medeiros 1501 - 4ํandar Ala Norte, Porto Alegre - RS. CEP:

90119.900 Brasil

cilulia-freitas@metroplan.rs.gov.br

\title{
A identificação de fragilidades na aplicação das leis de parcelamento do solo na Região Metropolitana de Porto Alegre, Brasil
}

The identification of weaknesses in the application of land subdivision laws in the Metropolitan Region of Porto Alegre, Brazil 
Referência: Guerra, Rosana et al. (2018). A identificação de fragilidades na aplicação das leis de parcelamento do solo na Região Metropolitana de Porto Alegre, Brasil. Revista de Geografia e Ordenamento do Território (GOT), n. ${ }^{\circ} 14$ (setembro). Centro de Estudos de Geografia e Ordenamento do Território, p. 225-250, dx.doi.org/10.17127/got/2018.14.009

\section{RESUMO}

O presente trabalho tem como objetivo principal propor uma reflexão acerca da aplicação das Leis de Parcelamento do Solo - Federal, Estadual e Municipais, utilizando como Estudo de Caso três projetos pertencentes à Região Metropolitana de Porto Alegre (RMPA). Como procedimentos metodológicos foram realizados: delimitação do objeto empírico de análise, identificação das principais leis de parcelamento do solo, seleção e análise de três projetos de parcelamento do solo. Dentre as principais contribuições desta pesquisa está a identificação de fragilidades nas leis que contribuem para: destinação de áreas públicas em locais inadequados, descontinuidade do sistema viário, superdimensionamento de quadras, ocupação em áreas de preservação permanentes e subversão do uso do instrumento de delimitação do perímetro urbano para conter a expansão horizontal da cidade.

Palavras-chave: aplicação das leis, parcelamento do solo, Região Metropolitana, Porto Alegre, Brasil.

\section{ABSTRACT}

The present work has as main objective to propose a reflection about the application of the Laws of Soil - Federal, State and Municipal Parcels, using as Case Study three projects belonging to the Metropolitan Region of Porto Alegre (RMPA in Portuguese). As methodological procedures were performed: the delimitation of the empirical object of analysis, the identification of the main Laws of land subdivision and the selection and analysis of three land parceling projects. Among the main contributions of this research is the identification of weaknesses in the Laws, which make it possible to: allocate public areas in inappropriate places, discontinuity of the road system, oversize of blocks, occupation in permanent preservation areas and subversion of the use of the instrument of delimitation of the urban perimeter to contain the horizontal expansion of the city.

Keywords: Application of laws, land subdivision, Metropolitan Region, Porto Alegre, Brazil.

\section{Introdução}

Cada vez mais o ambiente urbano se torna o local de residência no qual se desenvolvem as diversas atividades humanas (Barreiros e Abiko, 1998). No Brasil tem se verificado, nas últimas décadas, a aceleração do processo de urbanização da população. Em 2010, o Censo Demográfico já indicava que o Estado do Rio Grande do Sul possuía 85,1\% das pessoas morando nos centros urbanos contra $14,9 \%$ vivendo no campo. Esse imenso contingente de pessoas tem demandado a produção de espaço urbano para moradia e atividades. Parte 
dessa demanda é atendida por meio da verticalização de construções urbanas, enquanto a outra se desloca para novas áreas urbanas ou áreas em processo de urbanização (Barreiros e Abiko, 1998).

No Brasil, o processo de urbanização e produção de novas áreas urbanas nos municípios se realiza por meio do parcelamento do solo feito sob a forma de parcelamento, regular ou irregular (Barreiros e Abiko, 1998). Neste artigo será tratado o parcelamento do solo na forma regular. Os instrumentos de controle urbano definidos por nossos Planos Diretores têm sido duramente postos à prova, face aos desafios urbanos como a explosão de crescimento urbano desde a segunda metade do século XX (Netto e Saboya, 2010). Para propiciar a sustentação das atividades que serão desempenhadas em áreas urbanas, a expansão dos limites geográficos dessas áreas deve ser adequadamente organizada. A organização espacial desse novo tecido deve permitir o pleno desenvolvimento da população ali residente e integrar-se adequadamente à estrutura urbana existente.

Inserido no contexto e na problemática do fenômeno da urbanização, o parcelamento do solo é hoje um dos temas de maior relevância, tanto sob o aspecto técnico quanto no jurídico, no que se refere ao ordenamento da cidade, principalmente na organização espacial de novas áreas urbanas. Mota (1980), salienta que o parcelamento do solo, realizado sob a forma de loteamento ou desmembramento, é um dos instrumentos urbanísticos utilizados para promover a organização territorial dos municípios brasileiros. Por meio desse instrumento, o município pode exigir uma distribuição adequada dos lotes, equipamentos e vias públicas, bem como suas respectivas dimensões, taxas de ocupação, áreas para recreação, usos comunitários e infraestrutura mínima.

A regulamentação técnica e jurídica do parcelamento do solo se faz por meio de legislação urbanística. No universo das leis urbanísticas, a Lei Federal no 6.766/79 representou um marco no processo de parcelamento formal do solo urbano no Brasil, na medida em que buscou disciplinar a ocupação e a urbanização de novas áreas vinculadas à cidade préexistente. Além disso, ela é a grande diretriz urbanística do país, no que tange à expansão urbana regular após 1979, No sentido de garantir o cumprimento de seus dispositivos, a Lei Federal 6.766/79 previu o Termo de Anuência Prévia (TAP), que remete ao ente estadual a obrigatoriedade de examinar projetos de parcelamento do solo antes da aprovação final pelo ente municipal, aumentando assima proteção jurídica ao adquirente. 
Apesar de obrigatoriedade da TAP nas regiões metropolitanas do país, observa-se a existência de poucos órgãos de gestão e controle metropolitano. No Brasil apenas quatro órgãos metropolitanos exercem a emissão da TAP (RMs de Porto Alegre, Belo Horizonte, São Paulo e Recife), e outras duas RMs (Curitiba e Salvador) possuem órgãos que executam parcialmente esta função. Na ausência deste órgão, os projetos de parcelamento do solo são analisados e aprovados apenas nas instâncias municipais, sem levar em consideração seus impactos no âmbito supramunicipal.

No Estado do Rio Grande do Sul, e especificamente na Região Metropolitana de Porto Alegre (RMPA), a Fundação Estadual de Planejamento Metropolitano e Regional (METROPLAN), fundada em 1974, é o órgão responsável pela gestão metropolitana e emissão da TAP. A METROPLAN tem uma atuação ativa que busca garantir que os projetos de parcelamento do solo (loteamentos, desmembramentos e condomínios) aprovados estejam de acordo com a legislação urbanística que rege o uso do solo em território metropolitano, sendo a TAP uma exigência legal para o registro cartorial do projeto.

Um ponto a ser ressaltado na análise de projetos de parcelamento do solo para emissão da TAP é a problemática referente às fragilidades existentes nas Leis, as quais abrem diversas possibilidades para distintas interpretações que resultam, muitas vezes, em projetos que desqualificam o espaço urbano. Tais fragilidades se apresentam na forma de: modificações nas leis de parcelamento do solo (Gabe, 2017), pela subjetivida ou distorção na interpretação dessas leis (Maricato, 2003), assim como pelas divergências entre os conteúdos nos distintos níveis - Federal, Estadual e Municipal.

A partir do exposto, o presente trabalho tem como objetivo principal propor uma reflexão acerca da aplicação das Leis de Parcelamento do Solo - Federal, Estadual e Municipais, utilizando como Estudo de Caso três projetos pertencentes à Região Metropolitana de Porto Alegre (RMPA). Cabe destacar que este trabalho faz parte de um projeto de pesquisa que está em desenvolvimento. Na sequência desta pesquisa é apresentada, de forma detalhada, a RMPA, objeto empírico de estudo desta pesquisa. 


\section{Metodologia}

Como procedimentos metodológicos foram realizados: (i) a seleção do objeto de análise, (ii) a identificação das principais Leis que incidem sobre os projetos de parcelamento do solo e (iii) a seleção e análise de processos de parcelamento do solo, conforme apresentado na sequência.

\subsection{Objeto empírico de análise}

A RMPA foi instituída em 1973 e está situada no Estado do Rio Grande do Sul, na Região Sul do Brasil. Composta, inicialmente, por 14 municípios, e atualmente, por 34 municípios, a RMPA ocupa uma área total de $10.345,447 \mathrm{~km}^{2}$, na qual residem 4.282 .410 habitantes (IBGE, 2010). A conurbação, fenômeno da fusão dos tecidos urbanos de cidades próximas, restringe-se, em verdade, a não mais do que a metade deles e, com mais intensidade, àqueles 14 identificados em 1973, conforme apresentado na Figura 1.

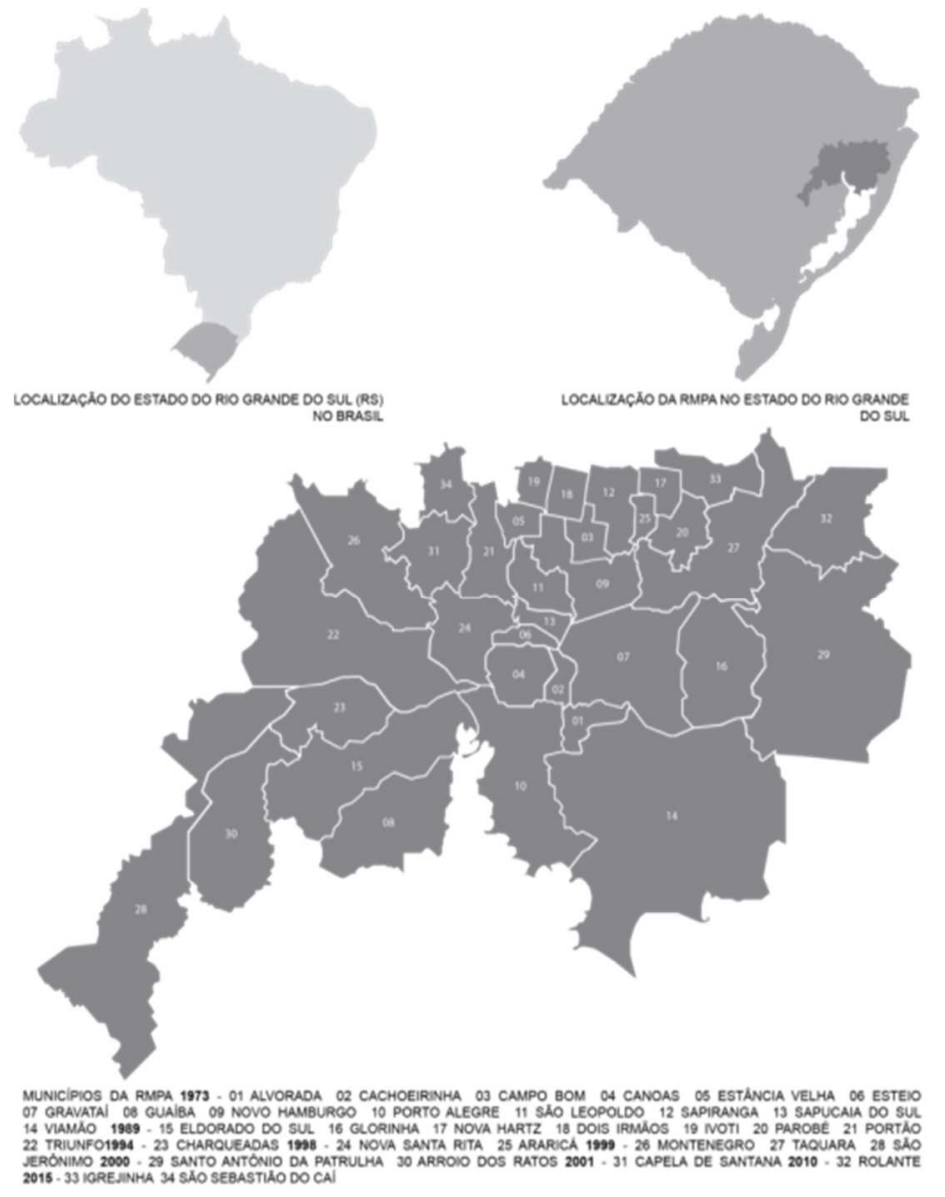

Figura 1 - Municípios pertencentes à RMPA

Elaborada pelos autores 2017 
A RMPA foi definida como objeto empírico de estudo desta pesquisa uma vez que é uma das quatro Regiões Metropolitanas brasileiras que ainda tem como atividade a emissão do TAP pelo órgão metropolitano, conforme já mencionado. A METROPLAN acumula a experiência de ter analisado, seguramente, mais de 7.000 projetos de parcelamento do solo na RMPA. A análise da viabilidade de implantação desses parcelamentos se dá por meio de análise de Leis específicas de parcelamento do solo apresentadas na sequência.

\subsection{Identificação das principais Leis de parcelamento do solo}

As principais Leis que regulam o parcelamento do solo no Rio Grande do Sul são: Lei Federal 6.766/79, Lei Estadual de Desenvolvimento Urbano 10.116/94 e as Leis Municipais (Planos Diretores e leis de parcelamento do solo). Concomitantemente, os parcelamentos também são regidos pelo Estatuto da Cidade, Lei Federal 10.257/01 e Leis ambientais, principalmente a Lei Federal no 12.651/12 que dispõe sobre a proteção da vegetação nativa. As fragilidades das referidas Leis são exploradas nesta pesquisa a partir da análise de processos de parcelamento do solo.

\subsection{Seleção e análise de processos de parcelamento do solo}

A METROPLAN realizou, desde a sua fundação em 1974, a análise de aproximadamente 7.000 projetos de parcelamento do solo urbano na Região Metropolitana de Porto Alegre. Entende-se por projetos de parcelamento, os desmembramentos, loteamentos e condomínios. Dentre esse universo, foram selecionados para discussão como Estudos de Caso neste trabalho, três projetos de parcelamento do solo. Esses projetos, em particular, foram selecionados por demonstrar, de forma clara, os conflitos legais encontrados na análise urbanística, os quais possibilitam gerar reflexões acerca das fragilidades existentes nas Leis de parcelamento do solo, objetivo principal desta pesquisa. A análise dos estudos de caso foi realizada sistematicamente em fases, sendo essas referentes à: (i)identificação do tipo de parcelamento e respectiva área em hectares (ii) localização da gleba no município por meio de pontos georreferenciados; (iii) identificação da(s) zona(s) onde localiza-se a gleba, conforme mapa de zoneamento do Plano Diretor Municipal, (iv) análise das Legislações Federal, Estadual e municipais pertinentes à cada caso estudado; (v) análise do 
projeto urbanístico e sua adequação em relação ao sistema viário pré-existente, às áreas públicas de doação, ao dimensionamento dos quarteirões e; (vi) análise dos condicionantes ambientais e das áreas de preservação permanente localizadas na gleba através da verificação da legislação ambiental vigente.

Cabe salientar que para manter o sigilo dos Estudos de Caso selecionados, tomou-se o cuidado de retirar qualquer informação pertinente à localização desses parcelamentos do solo. Os principais resultados obtidos são apresentados na sequência.

\section{Resultados}

Como principais resultados da presente pesquisa são apresentados: (i) a revisão das principais leis que regulam o parcelamento do solo urbano e (ii) a análise de processos de parcelamento do solo (Estudos de Caso 1, 2 e 3).

\subsection{Principais Leis que regulam o parcelamento do solo urbano}

No Brasil, até o final da década de 1970, o controle do parcelamento do solo foi exercido no âmbito Municipal (Ugalde, 2002). Com a aprovação da Lei Federal no 6.766, em 1979, que dispõe sobre o parcelamento do solo urbano na forma de desmembramento e loteamento, foram estabelecidas exigências com relação a requisitos técnicos e às obrigações dos proprietários dos empreendimentos. Do ponto de vista técnico, corresponderam à: superfície mínima de lotes; reserva destinada ao sistema viário e demais áreas públicas; vedação do parcelamento de áreas externas ao perímetro urbano legal e em locais ambientalmente contraindicados. A responsabilidade, tanto pela implantação de toda a infraestrutura necessária quanto pela comercialização dos lotes somente após a aprovação e registro do empreendimento, passou a ser exclusiva do proprietário ou loteador.

À denominada "autoridade metropolitana" foi atribuído o exame e a anuência prévia à aprovação municipal dos projetos de parcelamento do solo nos municípios integrantes da Região Metropolitana. 
A Lei Estadual no 10.116/94, aprovada em 23 de março de 1994, tem o objetivo de contribuir para o regramento jurídico do desenvolvimento urbano do Rio Grande do Sul. Entre seus diversos aspectos destacados se destaca a absoluta necessidade de instituição de um sistema permanente de planejamento municipal. O Plano Diretor Municipal determina critérios objetivos para o estabelecimento e ampliação de perímetros urbanos, reconhece a importância da reserva de espaços públicos, do patrimônio histórico e ambiental, da regularização fundiária e da participação comunitária.

Com relação ao parcelamento do solo, a Lei Estadual no 10.116/94 reforça muitos dos aspectos já mencionados na Lei Federal no 6.766/79. Os condomínios por unidades autônomas $^{1}$ foram equiparados a outras formas de parcelamento do solo urbano, o que já havia sido expresso anteriormente em diversas Leis municipais. A Lei Estadual passa a limitar os tamanhos dos condomínios, na tentativa de evitar grandes áreas segregadas (ilhas) dentro do tecido urbano.

A Lei Estadual no 10.116/94 reitera a exigência de reserva de áresa para uso público naqueles empreendimentos situados em glebas não parceladas previamente, o que demonstra coerência com relação à necessidade da presença de equipamentos comunitários e serviços também naqueles locais onde os condomínios estão sendo implantados.

Os primeiros documentos editados sobre a conurbação de Porto Alegre com outros municípios já apontavam para a necessidade de uma homogeneização da legislação urbanística.

\begin{abstract}
"Em verdade, mesmo as Leis que não forem passíveis de uma homogeneidade deverão ser estudadas em conjunto, para cada uma das áreas Municipais, no sentido de que promovam o desenvolvimento harmônico de toda a região..." (PORTO ALEGRE, 1987).
\end{abstract}

Nesse sentido, a legislação urbanística dos municípios da RMPA, de uma forma geral, é semelhante entre si, o que é resultado muito menos de um estudo conjunto do que da

\footnotetext{
${ }^{1}$ De acordo com a Lei № 4.591, de 16 de dezembro de 1964, Art. 10 As edificações ou conjuntos de edificações, de um ou mais pavimentos, construídos sob a forma de unidades isoladas entre si, destinadas a fins residenciais ou não-residenciais, poderão ser alienados, no todo ou em parte, objetivamente considerados, e constituirá, cada unidade, propriedade autônoma. Art. 7ํ, 0 condomínio por unidades autônomas instituir-se-á por inscrição obrigatória no Registro de Imóvel, dêle constando; a individualização de cada unidade, sua identificação e discriminação, bem como a fração ideal sôbre o terreno e partes comuns, atribuída a cada unidade, dispensando-se a descrição interna da unidade.
} 
necessidade de se obter, em prazo curto, um escopo legal mínimo para fazer frente à dinâmica de ocupação do território. Nesse sentido, com poucas condições de desencadear discussões objetivas sobre especificidades locais, as Municipalidades adaptam leis de outros municípios, acarretando muitas vezes a edição de inúmeras pequenas alterações, dificultando interpretações e prejudicando sua aplicabilidade.

Via de regra, o conjunto de Leis Municipais que regulam direta ou indiretamente o uso, a ocupação e o parcelamento do solo é constituído pelas Leis Orgânicas, do Perímetro Urbano, do Plano Diretor, de Zoneamento, de Parcelamento do Solo e do Código de Obras. O zoneamento de usos e as normas de parcelamento do solo, encontram-se muitas vezes contidas no Plano Diretor. Na RMPA, todos os municípios possuem a base legal, cujo conteúdo expressa as principais diretrizes de ordenamento territorial preconizada pelo planejamento urbano.

O zoneamento é um dos principais instrumentos de planejamento em uso em nossas cidades. O fato de um parcelamento ser promovido ilegalmente em zona rural dá ao Poder Público forte argumento para a imediata aplicação das medidas cabíveis. Com isso quer-se ressaltar a inconveniência da promoção de ampliações desnecessárias de perímetros urbanos, o que ocasiona grande ônus ao município pela dispersão da ocupação e subutilização da infraestrutura bem como a fragilização de seu poder de controlar a ocupação do território.

O estudo desenvolvido pela METROPLAN, em 1991, intitulado "Evolução dos perímetros urbanos da RMPA - 1970 a 1990" conclui:

(...) verifica-se que diversos municípios da RMPA alteram suas áreas urbanas com uma frequência muito elevada, criando ampliações que, na maioria dos casos, visam atender interesses de particulares. Assim, não se originam de um plano de zoneamento ou de diretrizes de ocupação, sendo pensadas isolada $e$ independentemente da área urbana vigente (...).

Muitas vezes a administração municipal busca a regularização de um loteamento implantado na zona rural, em local afastado do perímetro urbano. A extensão do perímetro urbano até o loteamento acaba por transformar em urbanas as glebas ainda sem uso urbano.

Posteriormente à identificação e discussão acerca das principais Leis que regulam o parcelamento do solo (Lei Federal n 6.766/79; Lei Estadual no 10.116/94, Leis Municipais), 
o artigo segue para a seleção dos três Estudos de Caso pertencentes à RMPA para reflexão acerca da aplicabilidade das Leis de parcelamento do solo, conforme objetivo principal da presente pesquisa.

\subsection{Estudo de Caso 1}

O Primeiro Estudo de Caso se refere a um projeto de loteamento com 10,48 ha, localizado em uma zona urbana já estruturada urbanisticamente, conforme Figura 2.

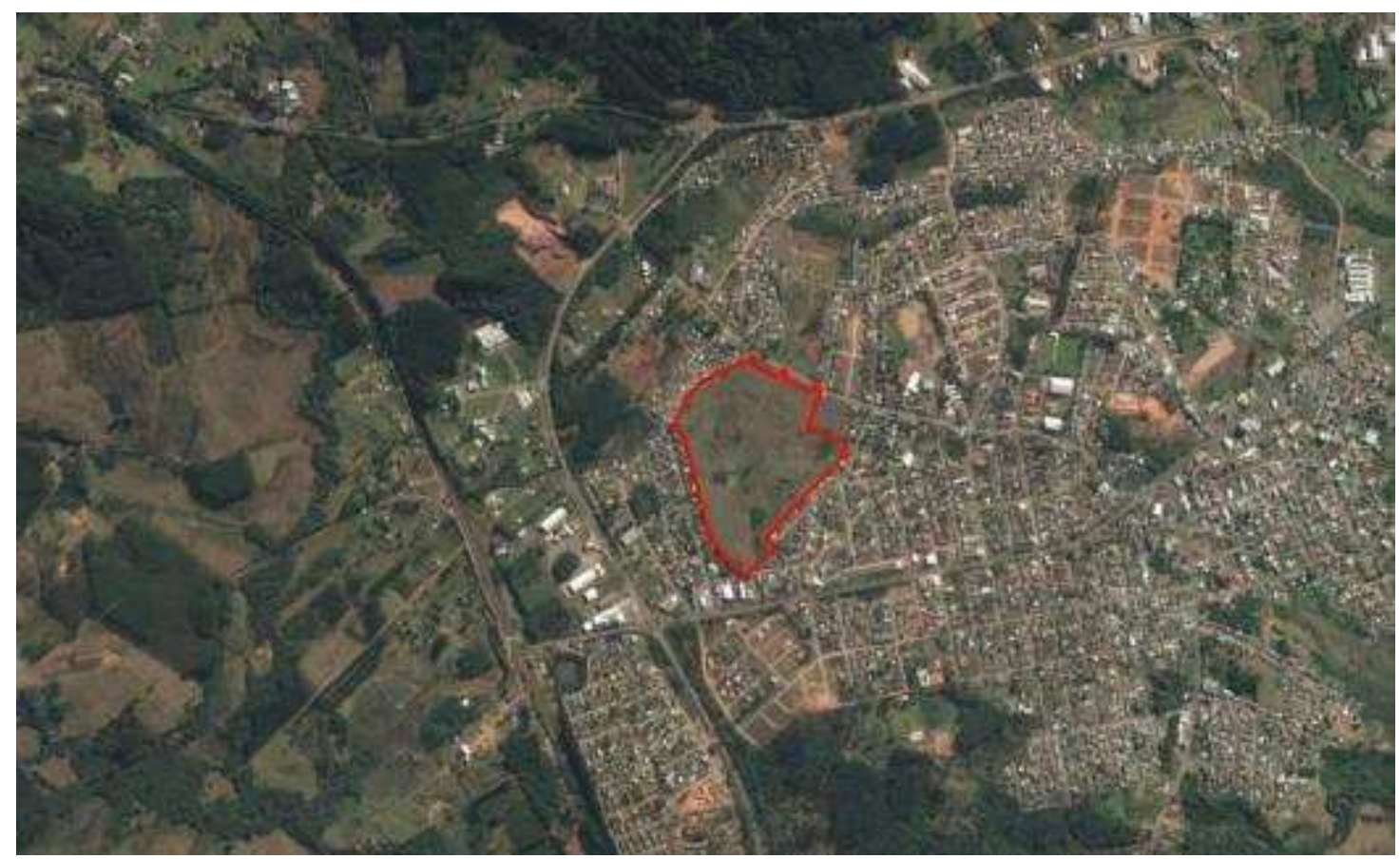

Gleba

Figura 2 - Imagem de satélite com demarcação da localização da gleba em vermelho.

Fonte: Google Earth (2017)

De acordo com o Plano Diretor Municipal a gleba localiza-se em Zona de Expansão da Ocupação, na Macrozona Urbana:

Art. 34. Fica definida como Macrozona Urbana a área que se caracteriza pela diversidade de usos, pela ocupação residencial intensiva e pela concentração de atividades de comércio e serviços especializados e edificações de interesse histórico.

DA ZONA DE EXPANSÃO DA OCUPAÇÃO - ZEO

Art. 13. Fica definida como Zona de Expansão da Ocupação - ZEO - aquela caracterizada pela existência de vazios urbanos com potencial de adensamento.

$\S 1$. - Para esta zona ficam estabelecidos os seguintes objetivos:

I- estimular o uso residencial;

II - expandir a rede de infraestrutura básica, equipamentos públicos comunitários e serviços públicos; 
III - dar continuidade ao sistema viário e à qualidade do desenho urbano;

IV - adequar da permissão de usos vicinais a partir de critérios de incômodos à vizinhança;

Conforme Legislação Municipal - Plano Diretor, o tipo de empreendimento proposto vem atender a uma demanda municipal importante: a carência de áreas residenciais providas de infraestrutura com serviços e equipamentos urbanos, áreas de lazer e recreação. A Gleba localiza-se em uma única zona e insere-se em uma área urbana com o entorno já consolidado, conforme pode ser observado nas Figuras 2 e 3.

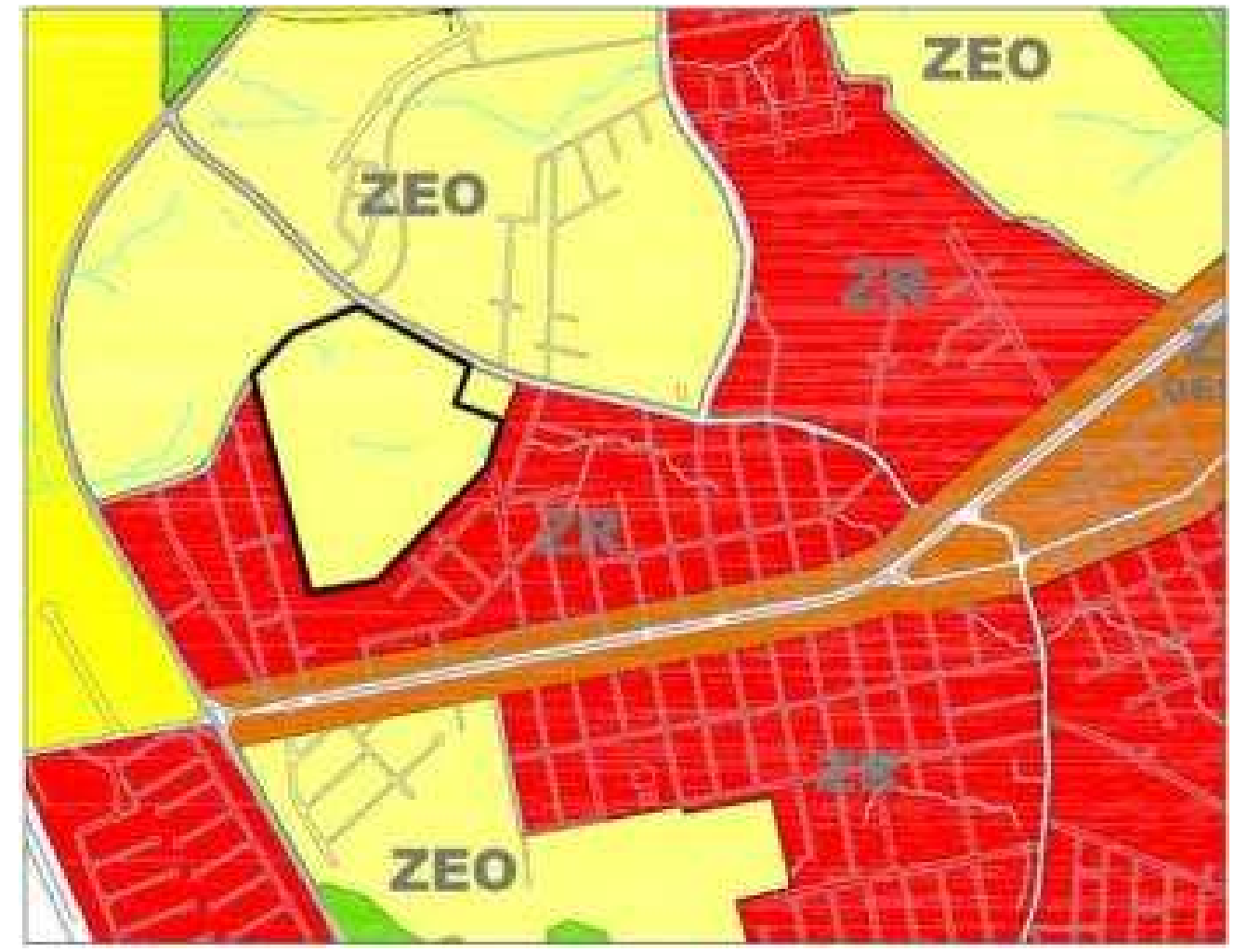

Figura 3- Mapa de Zoneamento da área METROPLAN, 2017

De modo geral, o projeto de loteamento contempla 355 lotes num total $104.822,38 \mathrm{~m}^{2}$ de quadras residenciais. Quanto às áreas de doação pública, estão sendo previstos $5,67 \%$ de Área Institucional, $11,57 \%$ de Área Verde e 22,91\% de sistema Viário. A área verde e institucional localizadas a sul da gleba possuem acesso por várias vias sem saída e tem limites com fundos de lotes, conforme Figura 4. 


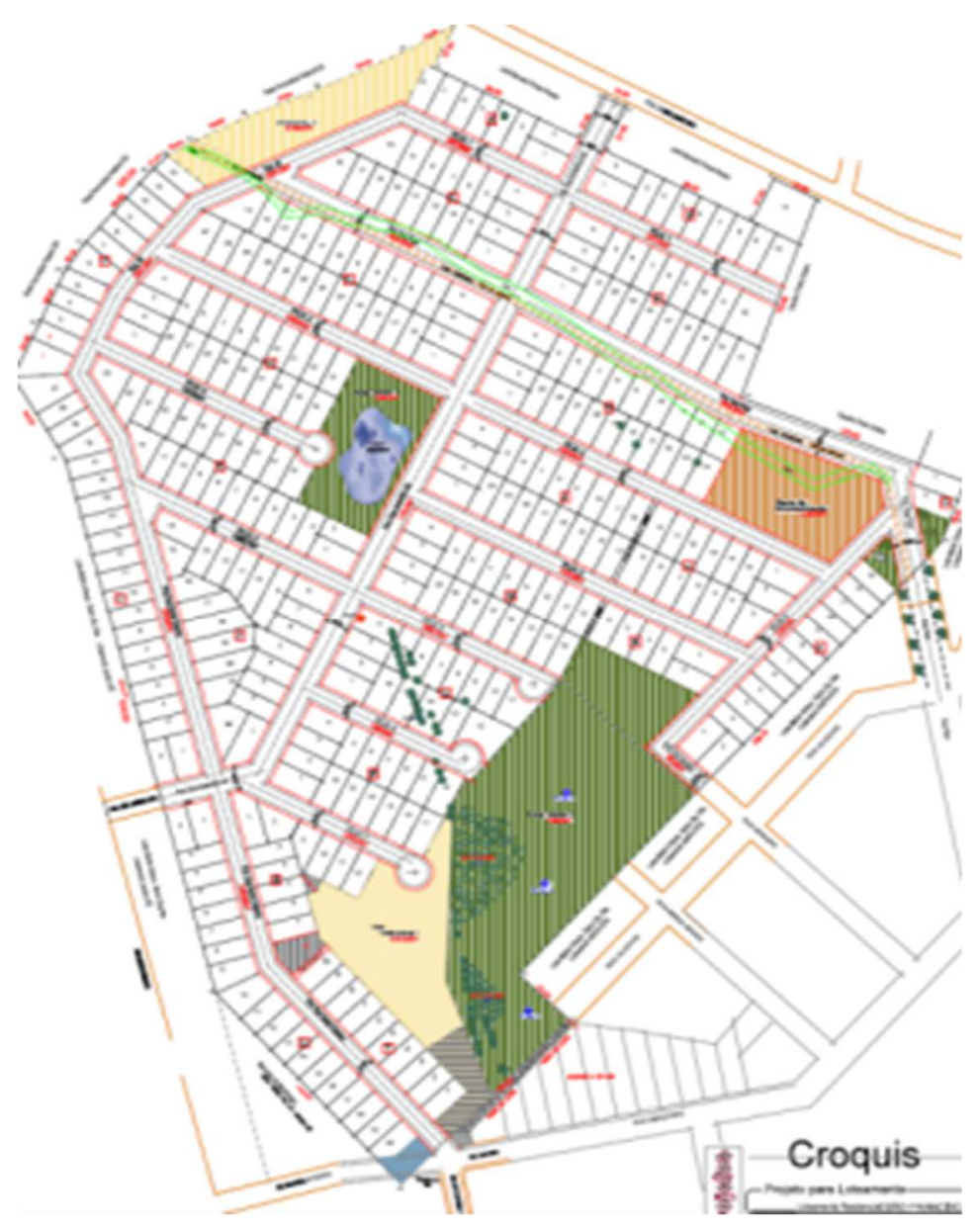

Figura 4 - Projeto de loteamento do Estudo de Caso 1 METROPLAN, 2017

A proposta apresentada na Figura 4 situa as áreas públicas em locais inadequados uma vez que não valoriza a centralidade dos equipamentos urbanos, a relação dos equipamentos com as vias públicas, com acessos por vias sem saída e limites com fundos de lotes

De modo complementar, a análise do projeto permite evidenciar que tais problemas são muito frequentes nos projetos de parcelamento do solo dos municípios da RMPA e podem ser atribuídos, em parte, à omissão do poder público em cumprir o seu papel de definir diretrizes conforme estabelece a Lei Federal 6.766/79 nos seus artigos 6으 e 7ㅇ․

Art. 6o Antes da elaboração do projeto de loteamento, o interessado deverá solicitar à Prefeitura Municipal, ou ao Distrito Federal quando for o caso, que defina as diretrizes para o uso do solo, traçado dos lotes, do sistema viário, dos 
espaços livres e das áreas reservadas para equipamento urbano e comunitário, apresentando, para este fim, requerimento e planta do imóvel...

Art. 7o. A Prefeitura Municipal, ou o Distrito Federal quando for o caso, indicará, nas plantas apresentadas junto com o requerimento, de acordo com as diretrizes de planejamento Estadual e Municipal:

I - as ruas ou estradas existentes ou projetada, que compõem o sistema viário da cidade e do município, relacionadas com o loteamento pretendido e a serem respeitadas;

II - o traçado básico do sistema viário principal;

III - a localização aproximada dos terrenos destinados a equipamento urbano $e$ comunitário e das áreas livres de uso público;

IV - as faixas sanitárias do terreno necessárias ao escoamento das águas pluviais e as faixas não edificáveis;

$V$ - a zona ou zonas de uso predominante da área, com indicação dos usos compatíveis.

Até o ano de 1999 havia, na Lei Federal de parcelamento do solo, a previsão de reserva de $35 \%$ da área total da gleba, para as áreas públicas. Cabe salientar que esse artigo foi revogado, mas no Rio Grande do Sul segue válido por meio do artigo 20 da Lei Estadual 10.116/94:

Art. 20 - A percentagem de áreas destinadas ao sistema viário e à implantação de equipamentos urbanos e comunitários será proporcional às densidades populacionais previstas para a gleba, e nunca inferior a 35\% (trinta e cinco por cento) da mesma, salvo nos loteamentos destinados ao uso industrial cujos lotes forem maiores do que $15.000 \mathrm{~m} 2$ (quinze mil metros quadrados), caso em que esta percentagem poderá ser reduzida.

Neste caso, a Lei é falha no sentido que apresenta percentuais adequados, mas não contempla critérios para a localização das áreas públicas.

Outro fator a considerar no projeto deste loteamento (Figura 4), é a descontinuidade do sistema viário existente. O projeto propõe vias sem saída e desconsidera vias importantes de articulação com o entorno. Novamente a falta de diretrizes específicas na Lei para cada gleba, contribui com a fragmentação e descontinuidade do sistema viário das cidades.

Cabe destacar que a previsão de continuidade viária e articulação com o entorno é prevista na Lei 6766/79:

Art. 4․ Os loteamentos deverão atender, pelo menos, aos seguintes requisitos: $I V$ - as vias de loteamento deverão articular-se com as vias adjacentes oficiais, existentes ou projetadas, e harmonizar-se com a topografia local.

No entanto, frequentemente, a preocupação com a continuidade das vias não é observada pelos projetistas.

Quanto ao tamanho dos quarteirões, observa-se no projeto utilizado como Estudo de Caso (Figura 4) que o quarteirão formado pelas quadras " $A$ ", "O" e "V", com uma extensão 
aproximada de $1.000 \mathrm{~m}$ de comprimento entre uma via e outra, ultrapassa a medida prevista no Plano Diretor para quarteirão estruturador em zonas urbanas, formando uma"superquadra".

Plano Diretor Municipal: DOS QUARTEIRÕES

Art. 8.. O comprimento dos quarteirões não poderá ser superior a 400,00m (quatrocentos metros).

Art. 9. Os quarteirões de mais de 200,00m (duzentos metros) de comprimento deverão ter passagens para pedestres no seu terço médio, no máximo, sendo que os recuos laterais das construções terão, no mínimo, 2,00m (dois metros) e não poderá haver frente de lotes voltados para as mesmas.

Art. 10. A largura máxima admitida para os quarteirões residenciais padrão será de $70,00 m$ (setenta metros).

No entanto, foi justificado, por parte do empreendedor, que a área lindeira possui um cinturão de ocupações com moradias irregulares e desta forma não permite a transposição de vias, só no caso de desapropriações ou reintegração de áreas .

Outra característica da área em estudo, é situar-se em terreno com declive em todo o seu perímetro, formando uma bacia na área central com cota mais baixa, úmida e brejosa. A Lei Federal no 12.651/12, que dispõe sobre a proteção da vegetação nativa, não prevê mais a proteção de ambiente de solo úmido.

Tendo em vista os fatores apresentados no Estudo 1, foi possível observar que a proposta de projeto apresenta várias soluções consideradas inadequadas que parecem desqualificar o espaço urbano. Logo, vê-se a necessidade de um posicionamento por parte da municipalidade, conforme recomenda a Lei Federal 6.766/79, definindo de forma mais clara as diretrizes para o uso do solo, traçado dos lotes, do sistema viário, dos espaços livres e das áreas reservadas para os equipamentos urbanos e comunitários.

\subsection{Estudo de Caso 2}

O segundo Estudo de Caso se refere a um projeto de loteamento com área de 6,0 ha, direcionado à população de baixa renda e localizado em área de expansão urbana, ainda não estruturada urbanisticamente, conforme Figura 5. 


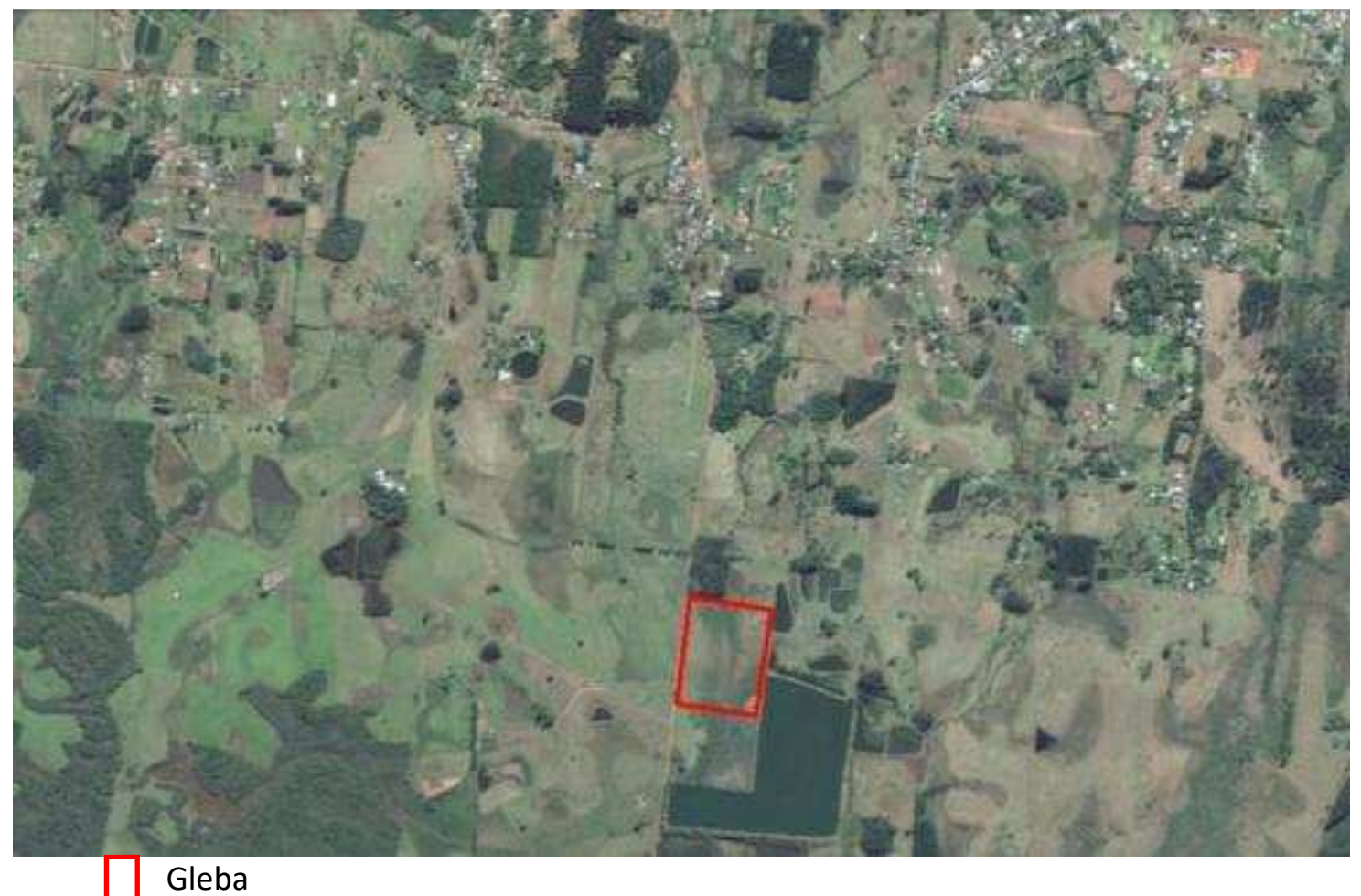

Figura 5 -Imagem de satélite com demarcação da localização da gleba em vermelho. Fonte: Google Earth (2017)

Nas análises iniciais a gleba encontrava-se em zona rural, conforme Plano Diretor Municipal e respectivo mapa de zoneamento, impedindo assim a continuação do processo de parcelamento do solo de acordo com o que estabelece a Lei Federal 6.766/79:

"Somente será admitido o parcelamento do solo para fins urbanos em zonas urbanas, de expansão urbana ou de urbanização específica, assim definidas pelo plano diretor ou aprovadas por lei Municipal." (Art. $3^{\circ}$ Lei Federal no 6.766/79).

Contudo, devido às constantes modificações da lei municipal, realizadas sem estudo prévio ou qualquer fundamentação técnica, a gleba foi inserida em Zona de Expansão Urbana caracterizada como Zona Residencial, após a subversão do uso do instrumento de delimitação do perímetro urbano. Percebe-se então uma tendência da lei municipal acompanhar os interesses particulares, resultando no efeito inverso da aplicabilidade do plano diretor municipal como instrumento básico da política de desenvolvimento e expansão urbana, ocorrência frequente na RMPA.

Conforme a Figura 6, o perímetro urbano cresce sem o respectivo avanço da malha viária. Ainda, o intervalo entre as modificações foi de apenas dois anos, não havendo nenhuma relação proporcional ao desenvolvimento da cidade e estimulando uma ocupação fragmentada e rarefeita que vai contra os princípios de sustentabilidade urbana e 
ambiental, bem como onerar a prestação de serviços pelo Poder Público ou manter a população residente mal atendida.
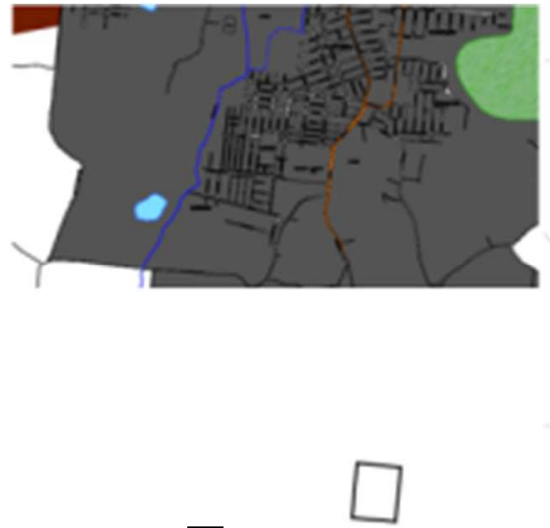

Área de estudo
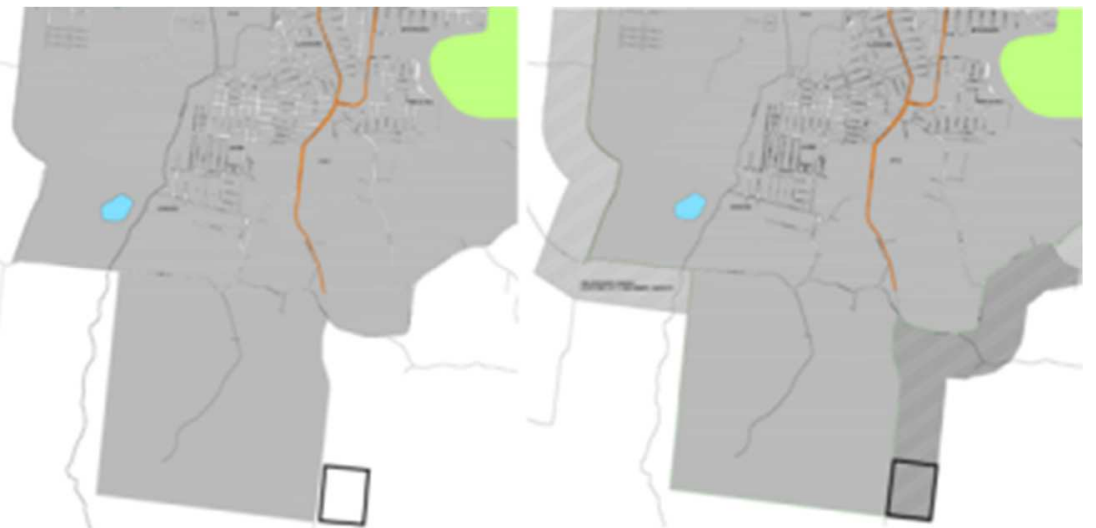

Figura 6 - A gleba e as alterações do perímetro urbano do município entre os anos de 2014 e 2016.

Elaborada pelos autores a partir de acervo da METROPLAN, 2017

Como se pode observar na Figura 7, o projeto urbanístico propõe um loteamento com 187 lotes, correspondendo a $60 \%$ da área total da gleba. Os outros $40 \%$ são destinados à área institucional, verde e de sistema viário, que correspondem às áreas que passam para o domínio público.

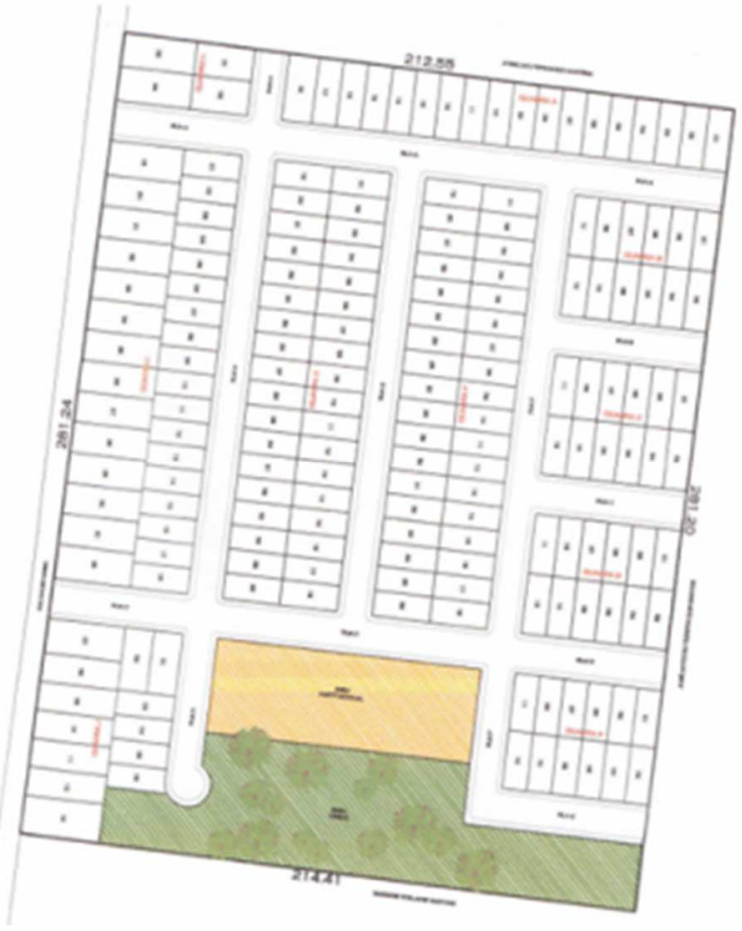

Figura 7 - Projeto urbanístico do Estudo de Caso 2 METROPLAN, 2017 
Outro ponto a salientar, tendo em vista a distância entre o empreendimento e o tecido urbano consolidado como mostra a Figura 6, é o afastamento da gleba em relação aos equipamentos urbanos que distam entre $1.700 \mathrm{~m}$ e $1.900 \mathrm{~m}$ da gleba, e estava em desacordo com a Lei Municipal 827/93 que estabelecia:

"Art. 10 - Somente será admitido o parcelamento do solo para fins urbanos, excetuados os destinados a sítios de lazer, quando a área situar-se em área urbana e no máximo a $1000 \mathrm{~m}$ (mil metros) dos seguintes melhoramentos construídos ou mantidos pelo poder público: a) via pavimentada; b) rede de abastecimento de água; c) rede de energia elétrica; d) escola de 1 o grau; e) ponto atendido por transporte coletivo" (Art. 10 Lei Municipal no 827/93).

Este artigo foi modificado pela lei 3663/2016:

"Art. 10 - Somente será admitido o parcelamento do solo para fins urbanos, excetuados os destinados a sítios de lazer, quando a área situar-se em área urbana e no máximo a 2000m (dois mil metros) (...)" (Art. 10 Lei Municipal no 3.663/16)

Percebe-se uma adaptação da legislação em favorecimento do interesse particular: a alteração admite uma distância de $2.000 \mathrm{~m}$, afastando a gleba do tecido urbano e desconsidera por completo os preceitos do urbanismo.

Cabe ressaltar, também, a ausência de infraestrutura básica necessária na via de acesso ao loteamento que viabilize a implantação do empreendimento conforme determina a Lei Federal 6.766/79:

"§ 50 A infraestrutura básica dos parcelamentos é constituída pelos equipamentos urbanos de escoamento das águas pluviais, iluminação pública, esgotamento sanitário, abastecimento de água potável, energia elétrica pública e domiciliar e vias de circulação." (Art. $2^{\circ}$ Lei Federal $n^{\circ}$ 6.766/79).

Tendo em vista os fatores apresentados no Estudo 2, foi possível observar que a proposta do projeto contém um caráter segregatório, no qual a população de baixa renda parece se inserir na periferia da cidade, não possuindo perspectiva de conexão com o restante do município. Logo, a área tende a ficar localizada em uma local isolado, de baixa densidade demográfica, descontínua e onerosa para a prestação de serviços urbanos. Os futuros moradores tendem a ficar segregados da cidade do ponto de vista locacional e social, considerando a dificuldade de deslocamento e consequentemente de acesso aos serviços públicos, como por exemplo, o de transporte. 


\subsection{Estudo de Caso 3}

O terceiro Estudo de Caso se refere a um projeto de condomínio de lotes $^{2}$ com 17,8 ha, direcionado a população de renda média e alta, localizado às margens do lago Guaíba, em uma zona urbana ainda não estruturada urbanisticamente, conforme Figura 8.

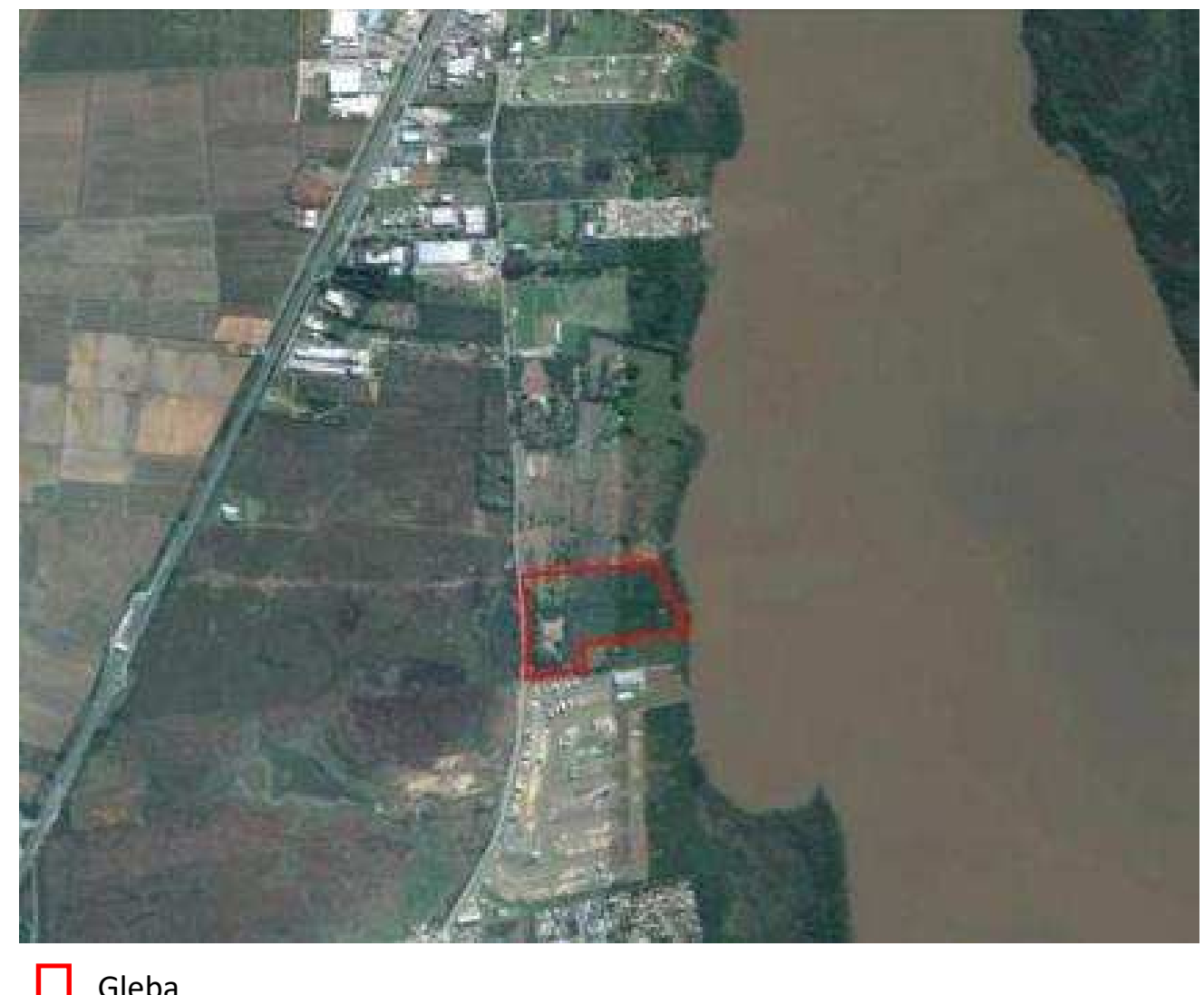

Figura 8 - Imagem de satélite com demarcação da localização da gleba em vermelho.

Fonte: Google Earth (2015)

De acordo com o Plano Diretor Municipal a gleba encontra-se em três zonas (Figura 9): Zona Especial de Interesse Ambiental Natural (ZEIAN) Zona Ambiental Especial Tipo 2 (ZA-E2) com tamanho máximo de quarteirão de $200 \mathrm{~m}$ de comprimento e 2,5 ha e Zona Ambiental Residencial Especial Tipo 2 (ZA-RE2) com 600m de comprimento e 24 ha. Para o desenvolvimento do projeto a Prefeitura Municipal autoriza adotar os padrões da zona predominante. O zoneamento diferenciado ao longo de vias importantes é um instrumento que reconhece o poder de atratividade que as vias exercem sobre atividades importantes, diferenciando naturalmente (mesmo quando não existe Lei de uso do solo) as atividades

\footnotetext{
${ }^{2}$ Com a Lei $n$ o 13.465/2017, surgiram duas novas espécies de condomínio: (1) o condomínio de lotes e (2) o condomínio urbano simples. O condomínio de lotes difere do loteamento, pois a propriedade do sistema viário e equipamentos comunitários não passa ao Poder Público municipal - ao contrário, permanece como propriedade dos condôminos.
} 
que se localizam junto às vias principais das que se implantam no "miolo" dos quarteirões.

Essa diferenciação é um aspecto positivo da Lei Municipal, que foi eliminado ao estender os padrões da outra zona.

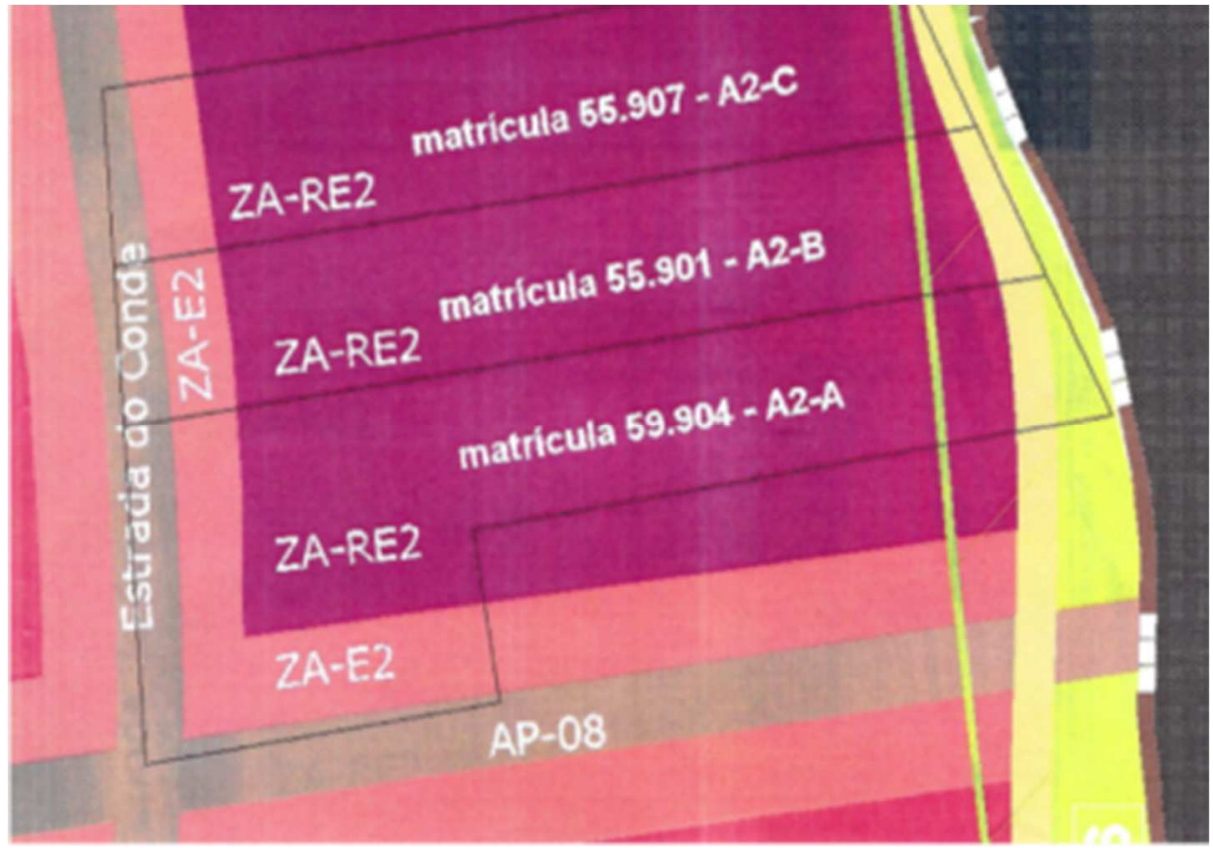

Figura 9 - Mapa de Zoneamento da área METROPLAN, 2017

O projeto propõe um condomínio fechado de lotes, com 135 lotes e $30 \%$ de áreas livres de uso comum e $40 \%$ de área de preservação permanente. Quanto às ruas, por ser um condomínio fechado, não propõe conexões viárias com o entorno. Somente considera a diretriz viária do Plano Diretor Municipal, lindeira ao condomínio. Cabe ressaltar que a Lei Federal 4.591/64 prevê somente o condomínio com edificações, assim como a Lei Estadual 10.116/94, que prevê a instituição de condomínios por unidades autônomas para a construção de mais de uma edificação sobre o terreno. A forma de parcelamento "condomínio de lotes" não está prevista na legislação urbanística.

Parte da gleba localiza-se sobre área de Preservação Permanente, conforme artigo 4으 da Lei Federal no 12.651/2012, que dispõe sobre a proteção da vegetação nativa:

Considera-se Área de Preservação Permanente, em zonas rurais ou urbanas, para os efeitos desta Lei:

I - as áreas no entorno dos lagos e lagoas naturais, em faixa com largura mínima de:

b) 30 (trinta) metros, em zonas urbanas;

Em adição, o Plano Diretor Municipal propõe um futuro Parque de Orla na extremidade leste da gleba. A implantação de um condomínio murado "de costas para o parque" com 
uma extensão de aproximandamente 300m (conforme Figura 10), vai de encontro aos

princípios urbanísticos de produção de espaços públicos acessíveis a toda a população.

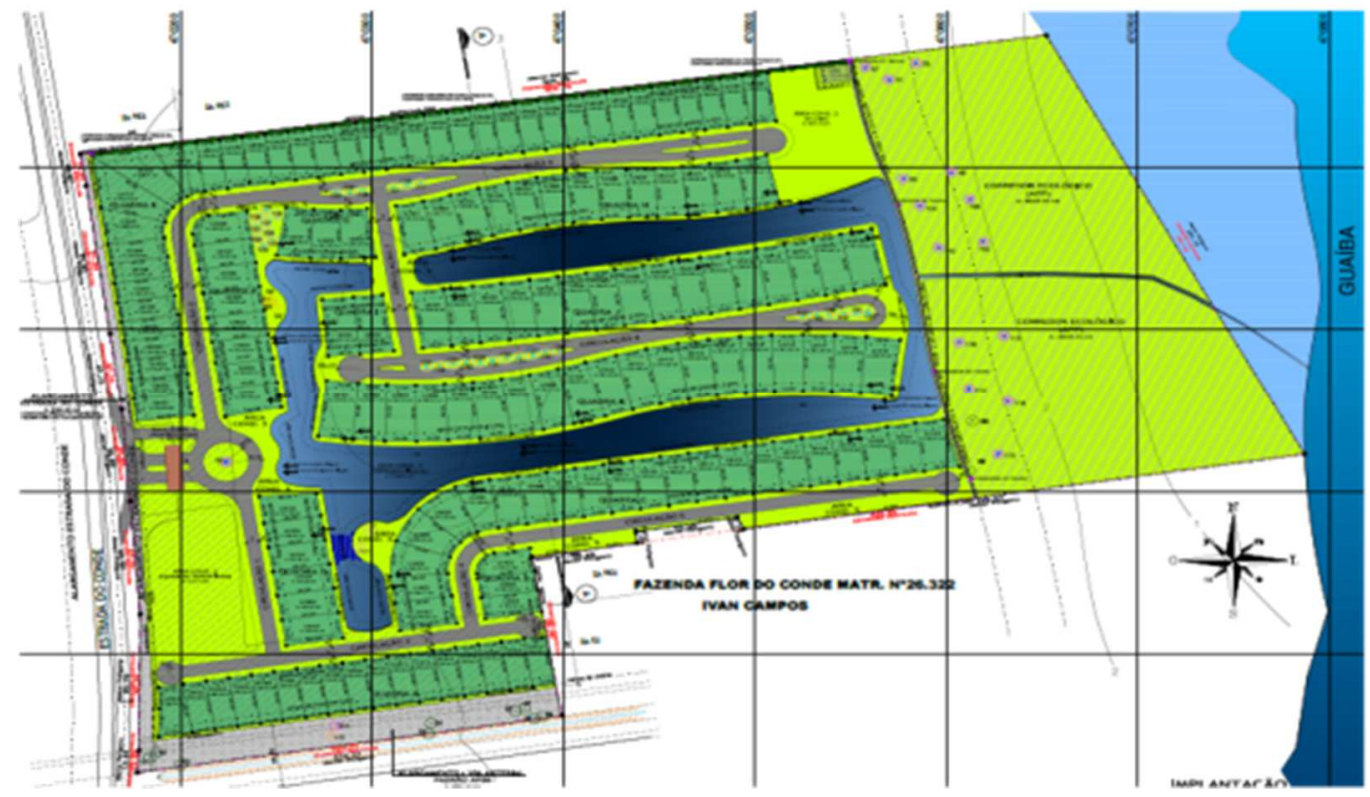

Figura 10 - Projeto urbanístico do Estudo de Caso 3

METROPLAN, 2017

Considerando que o Art. 5o da Lei Estadual 10.116/94 estabelece:

"Na promoção do desenvolvimento urbano, o município deverá:

I - definir a política Municipal de desenvolvimento urbano, em consonância com as diretrizes nacionais e Estaduais (...)"

Entende-se que os demais dispositivos da legislação Estadual reguladores do parcelamento do solo dos condomínios por unidades autônomas (artigo 25 e 26) devam ser também observados pela Municipalidade:

"Na instituição de condomínios por unidades autônomas será observado o limite máximo de $30.000 \mathrm{~m} 2$ (trinta mil metros quadrados) de área e testada para logradouro público não superior a 200m (duzentos metros). Parágrafo único - o município poderá excepcionar do disposto neste artigo, os condomínios a serem implantados em zonas já estruturadas urbanisticamente onde a rede viária existente tornar inadequadas as dimensões de testada e área máximas."(Art. 25 Lei Estadual no 10.116/94)

"Nos condomínios por unidades autônomas serão preservadas áreas livres de uso comum em proporção a ser definida pelo município e nunca inferior a $35 \%$ (trinta e cinco por cento) de área total da gleba. § 1 o - Quanto à gleba de que trata este artigo não tiver sido objeto de loteamento anterior e dele não tenha resultado prévia doação de área pública deverá ser destinado 10\% (dez por cento) do total da gleba para uso público, em localização a ser definida pelo município." (Art. 26 Lei Estadual no 10.116/94).

No caso em questão, o projeto utilizado como Estudo de Caso apresenta tamanho de quarteirão e testada superiores ao permitido pela legislação Estadual, com 17,8 ha, e 250m. 
No entanto, essa dimensão é admitida pelo Plano Diretor Municipal, evidenciando uma divergência entre as Leis Estadual e Municipal.

Cabe ressaltar que não se aplica o parágrafo único, acima citado, da Lei Estadual no 10.116/94, pois esse instrumento só pode ser utilizado para exceções em zonas já estruturadas urbanisticamente. O conceito de zonas já estruturadas e o tamanho que pode ser excepcionado é alvo de discussões frequentes entre estado e municípios, embora seja claro que uma zona está estruturada quando ao menos a malha viária principal já está implantada. Não basta haver vias previstas no plano municipal sem prazo para execução.

O limite de 3ha nas glebas não parceladas condiz com uma preocupação de ordem urbanística no sentido de que não haja barreiras à circulação urbana tanto de veículos como de pedestres. Vale dizer que é o loteamento urbano que efetivamente estrutura as cidades, porque é através dele que se viabiliza não só a continuidade viária como também a implantação de equipamentos públicos de uso comunitário e construção de redes de infraestrutura.

Outro ponto a ser destacado neste projeto é que não especifica onde será doada a área pública. No Plano Diretor deste município, o percentual de doação é 15\% para essas Zonas, superior ao requerido pela Lei Estadual. Ao dizer “... em localização a ser definida pelo município", a Lei 10.116/94 demonstra que a doação das áreas públicas deve ser feita em área. No entanto, o poder público municipal além de não determinar a localização da área pública, admite que possa ser feita sob a forma de valor monetário. Outra divergência entre Leis de diferentes níveis.

Do ponto de vista urbanístico, essa previsão da Lei Municipal é negativa, uma vez que a população do condomínio, mesmo tendo alguns equipamentos dentro, demandará outros equipamentos públicos como escola, posto de saúde, que poderão estar distantes do empreendimento. Em adição, devido ao impacto que um condomínio com extensão de área murada causa no entorno, a doação de áreas públicas na própria gleba (mas fora do condominio), poderia mitigar o efeito do fechamento. Outro aspecto a ser observado é a questão monetária, uma vez que a avaliação da área é subjetiva e o valor arrecadado nem sempre parece ir para as áreas públicas. 
Tendo em vista os fatores apresentados no Estudo 3, foi possível observar que a proposta parece fragmentar a cidade ao propor barreiras para delimitação do empreendimento. Esse fato deve-se pela proposta de muros que passam a delimitar e, de certo modo isolar, os moradores do restante do entorno urbano, impactanto de forma negativa a continuidade do sistema viário, circulação urbana e a conexão com o futuro parque de orla, localizado na porção leste do empreendimento.

\section{Conclusões}

Dentre as principais contribuições desta pesquisa está a identificação de fragilidades nas Leis, as quais possibilitam: (i) destinação de áreas públicas em locais inadequados, (ii) descontinuidade do sistema viário, (iii) superdimensionamento de quadras, (iv) ocupação em áreas de preservação permanentes e (v) a subversão do uso do instrumento de delimitação do perímetro urbano para conter a expansão horizontal da cidade.

A proposta de parcelamento apresentada no Estudo 1 parece apresentar soluções que desqualificam o espaço urbano ao priorizar um maior número de lotes residencias para comercialização e desconsiderar a continuidade do sistema viário existente e a localização dos espaços destinados ao uso público, como áreas de recreação e institucional. Já a proposta apresentada no Estudo 2 possibilitou observar que o projeto tende a potencializar um caráter segregatório, no qual a população de baixa renda é inserida na periferia da cidade, sem acesso à infraestrutura básica e equipamentos de uso público, não possuindo perspectiva de conexão com o restante do município,. A proposta de parcelamento apresentada no Estudo 3, por sua vez, tende a fragmentar a cidade ao propor barreiras (muros) para delimitação do empreendimento e ainda não prevê a doação do percentual adequado de área pública, o que representa um prejuízo ao município e à população local.

A abordagem dos três Estudos de Caso adotados nesta pesquisa evidenciaram, de forma clara, a necessidade de maiores especificações nas leis que regulamentam o parcelamento do solo, como por exemplo, localização mais adequada para áreas destinadas ao uso público do empreendimento. Além disso, os estudos evidenciam certa omissão por parte das prefeituras municipais, que de acordo com o artigo 60 da Lei Federal de Parcelamento do 
Solo $6766 / 79$ devem fornecer diretrizes projetuais para os parcelamentos, como diretrizes viárias e localização das áreas públicas e equipamentos comunitárioso que em grande parte dos casos não acontece. Em alguns casos o município expede boas diretrizes urbanísticas, como por exemplo: "as áreas públicas deverão estar em local central, com assessibilidade, testada para a via e preferencialmente não fazer limites com fundos de lotes" e no entanto aceita projetos que vão de encontro às diretrizes fornecidas. Concomitante a maiores especificações, tais leis parecem carecer de um olhar integrado do seu conteúdo, como é o caso das Leis Estadual e Municipal, no qual a primeira permite o parcelamento na forma de condomínio com área de 3 ha e a segunda de 24ha, conforme evidenciado no Estudo 3 desta pesquisa.

Cabe salientar que o Estado do Rio Grande do Sul enfrenta dificuldades no controle e na análise do parcelamento do solo, principalmente em virtude dessas fragilidades identificadas e discutidas nesta pesquisa. Além das Leis Estaduais e Municipais já mencionadas, as Leis ambientais também se apresentam frágeis do ponto de vista político uma vez que parecem sofrer alterações em benefício de poucos.

A subjetividade presente no conteúdo de determinadas leis tende a abrir margens para distintas interpretações. Tais interpretações dificultam o trabalho de análise por parte do órgão estadual que, muitas vezes, ao sugerir melhores soluções para os projetos, do ponto de vista urbanístico, visando o que é melhor para a cidade, encontra resistência por parte dos empreendedores que já tiveram seus projetos análisados no âmbito municipal. Visando aprofundar as reflexões geradas nesta pesquisa quanto à fragilidade das Leis - Federal, Estadual e Municipais, sugere-se para futuras pesquisas uma análise dos processos de parcelamento do solo de outros Regiões Metropolitanas, visando a possibilidade de comparação dos resultados gerados neste trabalho com outras situações brasileiras. Ainda, visando aprofundar a discussão sobre o tema, sugere-se uma revisão da eficácia na aplicação dessas leis e a possibilidade de maior especificidade. Em adição, sugere-se que o poder público municipal assuma seu papel e busque o melhor para a cidade e seus habitantes, através de diretrizes municipais específicas para cada projeto, considerando suas particularidades. E que os órgãos Estadual e municipais consigam trabalhar em conjunto para atender a demanda dos municípios da RMPA. 
Por fim, espera-se que as reflexões geradas nesta pesquisa resultem em um posicionamento das distintas esferas - Federal, Estadual e Municipal, quanto à necessidade de uma maior integração e/ou compatibilização entre as leis que regulam o parcelamento do solo.

\section{Agradecimentos}

Os autores agradecem os Arquitetos Urbanistas Cláudio Ugalde, Gilda Jobim, à Socióloga Jussara Pires e à acadêmica de Arquitetura e Urbanismo Helena Vogt pelas valiosas contribuições para o desenvolvimento desta pesquisa.

\section{Referências bibliográficas}

BARREIROS, M. A. F.; ABIKO, A. K. Reflexões sobre o Parcelamento do Solo Urbano, São Paulo - 1998. ISSN 0103-9830.

BRASIL. Código Florestal Brasileiro, Lei 12.651, de 25 de maio de 2012. Dispõe sobre a proteção da vegetação nativa; altera as Leis nos 6.938, de 31 de agosto de 1981, 9.393, de 19 de dezembro de 1996, e 11.428, de 22 de dezembro de 2006; revoga as Leis nos 4.771, de 15 de setembro de 1965, e 7.754, de 14 de abril de 1989, e a Medida Provisória no 2.166-67, de 24 de agosto de 2001; e dá outras providências.

BRASIL. Lei n. 4.591, de 16 de Dezembro de 1964. Dispõe sobre o condomínio em edificações e as incorporações imobiliárias.

BRASIL. Lei 6.766, de 19 de dezembro de 1979. Dispõe sobre o Parcelamento do Solo Urbano e dá outras Providências. República Federativa do Brasil, Poder Executivo, Brasilia, DF.

BRASIL. Lei Complementar n. 14, de 8 de Junho de 1973. Estabelece as regiões metropolitanas de São Paulo, Belo Horizonte, Porto Alegre, Recife, Salvador, Curitiba, Belém e Fortaleza.

BRASIL. Lei 10.257 de 10 de julho de 2001: Regulamenta os artigos 182 e 183 da Constituição Federal, estabelece diretrizes gerais da política urbana e dá outras providências. Brasília: Congresso Nacional.

BRASIL. Lei Complementar n. 13.465, de 11 de Julho de 2017.

BRASIL. Lei Estadual 10.116, de 23 de março de 1994. Institui a Lei do Desenvolvimento Urbano, que dispõe sobre os critérios e requisitos mínimos para a definição e delimitação de áreas urbanas e de expansão urbana, sobre as diretrizes e normas gerais de parcelamento do solo para fins urbanos, sobre a elaboração de planos e de diretrizes gerais de ocupação do território pelos municípios e dá outras providências.

GABE, M. Flexibilização do perímetro urbano e suas repercussões sobre a expansão urbana: Estudo de Lajeado/RS (1984-2016). Dissertação de Mestrado apresentada ao Programa de Pós-Graduação em Planejamento Urbano e Regional da Universidade Federal do Rio Grande do Sul (PROPUR/UFRGS). 2017.

IBGE - Fundação Instituto Brasileiro de Geografia e Estatística (10 de outubro de 2010).«Área territorial oficial». Resolução da Presidência do IBGE de no 5 (R.PR-5/02). Acesso em 10 de julho de 2017.

MARICATO, E. Metrópole, legislação e desigualdade. Revista Estudos Avançados, São Paulo, v. 17, p. 151-166, 2003. 
METROPLAN. Evolução dos perímetros urbanos da região metropolitana de Porto Alegre. Porto Alegre, 1991. (Documento Interno)

MOTA, F. S. B. Disciplinamento do uso e ocupação do solo urbano visando a preservação do meio ambiente. São Paulo, 1980, 254p. Tese (Doutorado)- Faculdade de Saúde Pública. Universidade de São Paulo.

NETTO, V. M.; SABOYA, R. T. A urgência do planejamento a revisão dos instrumentos normativos de ocupação urbana. Arquitextos, São Paulo, ano 11, n. 125.02, Vitruvius, out. 2010. ISSN 1809-6298.

PORTO ALEGRE. Secretaria Municipal de Obras e Viação. Divisão de Urbanismo. Região Metropolitana estudos. Porto Alegre, 198.

UGALDE, C. M. O parcelamento do solo na região metropolitana de Porto Alegre, efeito das decisões locais na configuração do espaço urbano-regional. 2002. 237f. Dissertação (Mestrado em Planejamento Urbano e Regional) - Programa de Pós-Graduação em Planejamento Urbano e Regional, Universidade Federal do Rio Grande do Sul. 